\title{
Food Security and Climate Change in Rural Eastern Uganda
}

\author{
T. Filipponi, P. Jarvis and A. Harris \\ University of South Wales, CF37 4BD, UK.
}

The Republic of Uganda has one of the fastest growing economies in Africa and has been regarded as the 'bread basket' of Eastern Africa $^{(1)}$. Although food production would be sufficient to satisfy the requirements of a rapidly growing population, in 2016 malnutrition was the top risk factor contributing to DALYs (death and disability combined) $)^{(2)}$. The prevalence of stunting in the Mbale District, eastern region of Uganda, was $>25$ percent and undernutrition disproportionately affects rural areas ${ }^{(3)}$. Furthermore, changes in climate patterns threaten to worsen food insecurity ${ }^{(4)}$. The aim of this study was to analyse food consumption patterns and dietary diversity in the rural Mbale District.

One hundred participants resident in the rural region of Mbale, Uganda (66 females; 34 males) aged 18-70 years old with the majority (>60 percent) aged 30-40 years old, completed a food frequency questionnaire (FFQ). The FFQ was aimed at collecting data on dietary intake over the previous year in relation to wet and dry seasons. Shapiro-Wilk tests indicated that data were not normally distributed; therefore, Wilcoxon tests were performed to determine differences in food consumption between wet and dry seasons. Statistical significance was established at $\mathrm{p}<0.05$.

The table below displays food types that showed statistically significant increases in consumption in the wet season compared to the dry season out of the seventeen food items analysed [e.g. maize (posho), cassava, meat, eggs, etc.]. The main carbohydrate sources, which were affected in the wet season, were matoke (mashed boiled savoury banana) and sweet and Irish potatoes. Furthermore, the main sources of protein, beans and groundnuts, were both affected by the seasons with an increased consumption during the wet period. Fruit and vegetables consumption was also greater in the wet season.

\begin{tabular}{|c|c|c|c|c|c|c|c|c|}
\hline $\begin{array}{l}\text { Wet Season } \\
\text { vs. } \\
\text { Dry Season }\end{array}$ & Number of meals & Matoke & Sweet Potatoes & $\begin{array}{c}\text { Irish Potatoes } \\
2023 \\
2082\end{array}$ & 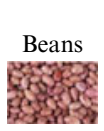 & $\begin{array}{c}\text { Groundnuts } \\
\text { sis }\end{array}$ & $\begin{array}{l}\text { Vegetables } \\
\text { ofy }\end{array}$ & 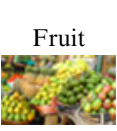 \\
\hline $\begin{array}{l}\mathrm{z} \\
\mathbf{p}\end{array}$ & $\begin{array}{l}-4.951 \\
<.001 *\end{array}$ & $\begin{array}{l}-4.117 \\
<\cdot 001 *\end{array}$ & $\begin{array}{r}-3.239 \\
.001^{*}\end{array}$ & $\begin{array}{r}-2.953 \\
.003^{*}\end{array}$ & $\begin{array}{r}-1.911 \\
.056^{* *}\end{array}$ & $\begin{array}{r}-2.841 \\
.005^{*}\end{array}$ & $\begin{array}{l}-4.780 \\
<.001 *\end{array}$ & $\begin{array}{l}-3.489 \\
<.001^{*}\end{array}$ \\
\hline
\end{tabular}

${ }^{*} P<0 \cdot 05 ; *$ near significant.

The impact of climate change is likely to have significant implications for agriculture, food security, soil and water resources. Mbale District normally receives enough rainfall for crops, but as the climate changes, the seasonal patterns are expected to become more extreme $^{(5)}$. Although matoke (savoury banana) and potatoes are the main staples in the region, posho (a dish of maize flour cooked with water to a porridge) and cassava are also consumed. The latter shows little loss as it is more resistant to variability in climate ${ }^{(5)}$. However, beans and groundnuts, which are also the main sources of protein in the diet of rural households, are also most sensitive to climate variations and have important implications for food security. Their production could be hindered with increasing climate instability $^{(5)}$. This could negatively impact the diet of the most vulnerable: children and women of reproductive age, especially during times of crisis.

1. USAID (2016) Uganda Nutritional Profile.

2. Institute for Health Metrics and Evaluation (2016) Uganda.

3. Walakira EJ, Muhangi D, Munyuwiny S et al. (2016) The State of the Ugandan Child - An Analytical Overview. Kampala/Washington DC: USAID/QED.

4. Uganda Bureau of Statistics \& World Food Programme (2013) Comprehensive Food Security and Vulnerability Analysis (CFSVA).

5. Ramirez-Villegas J \& Thornton PK (2015) Climate change impacts on African crop production. CCAFS Working Paper no. 119. CGIAR Research Program on Climate Change, Agriculture and Food Security (CCAFS). Copenhagen, Denmark. 